\section{FRI0330 MALIGNANCIES IN SYSTEMIC SCLEROSIS PATIENTSWITH ANTI-PM/SCL ANTIBODIES: AN EUSTAR CASE- CONTROL STUDY}

Maria Grazia Lazzaroni ${ }^{1}$, Stefania Zingarelli ${ }^{1}$, Jeska de Vries-Bouwstra ${ }^{2}$, Eric Hachulla ${ }^{3}$, Elisabetta Zanatta ${ }^{4}$, Simone Barsotti ${ }^{5}$, Marie-Elise Truchetet ${ }^{6}$, Giacomo De Luca ${ }^{7}$, Vanessa Smith ${ }^{8}$, Ellen De Langhe ${ }^{9}$, Roger Hesselstrand ${ }^{10}$, Francesca Ingegnoli ${ }^{7}$, Cristian Caimmi ${ }^{11}$, Silvia Bellando Randone ${ }^{12}$, Enrico Colombo ${ }^{13}$, Angela Ceribelli ${ }^{14}$, Franco Franceschini ${ }^{1}$, Yannick Allanore ${ }^{15}$ Paolo Airò'. ' ${ }^{-}$-, Brescia, Italy; ${ }^{2}$-, Leiden, Netherlands; ${ }^{3}$-, Lille, France; ${ }^{4}$-, Padova, Italy, ${ }^{5}-$, Pisa, Italy, ${ }_{-}^{6}$, Bordeaux, France; ${ }^{7}{ }_{-}$, Milano, Italy, ${ }^{8}-$, Ghent, Belgium; ${ }^{9}{ }_{-}$, Leuven, Belgium; ${ }^{10}$-, Lund, Sweden; ${ }^{11}{ }^{-}$, Verona, Italy, ${ }^{12}{ }^{-}$, Firenze, Italy; ${ }^{13}$, Sassari, Italy; ${ }^{14}$-, Rozzano, Italy; ${ }^{15}{ }_{-}$, Paris, France

Background: The main clinical associations of anti-PM/Scl in Systemic Sclerosis (SSc) include calcinosis, joint and muscle involvement, interstitial lung disease (ILD), and, possibly, scleroderma renal crisis (1,2). A possible association of anti-PM/Scl with cancer was reported in single-centre SSc series (2,3), but was never analysed in large multicentre studies. Moreover, the characteristics of malignancies, in particular their temporal association with the onset of SSc, were not explored.

Objectives: To evaluate the association of anti-PM/Scl with malignancies in a large, international, multicentre cohort.

Methods: 16 EUSTAR centres provided data on anti-PM/Scl+ SSc patients in their cohorts (cases), and on anti-PM/Scl-negative controls, matched for sex, age at onset ( \pm 5 years), cutaneous subset, and disease duration ( \pm 24 months). Only SSc patients with age $>16$ years at disease onset were included in this analysis. Anti-RNA Polymerase3+ patients were not included in controls, given the known association with synchronous cancer. Malignancies diagnosed between 2 years before and after the onset of SSc were defined as "synchronous to the onset of SSc". Results: 123 anti-PM/Scl+ SSc patients and 160 matched anti-PM-Sclcontrols (28\% anti-Topoisomerase I, 40\% anti-centromere, 32\% others) were compared (Table 1): anti-Pm/Scl+ patients had a higher prevalence of myositis $(p<0.0001)$ and ILD $(p<0.0001)$, and a lower prevalence of oesophageal symptoms $(p<0.0001)$. The frequency of malignancies was not significantly different between the 2 groups $(14 / 120$ (12\%) vs. $9 / 155$ $(6 \%), p: 0.12)$. Only 7 malignancies synchronous to SSc onset were identified: 4 among anti-PM/Scl+ cases and 3 among controls ( 3 breast cancers; 3 other solid tumours; 1 multiple myeloma). Mean age at SSc onset was significantly higher in patients with synchronous malignancies compared to those without $(64.9 \pm 7.2$ vs. $48.4 \pm 14.5$ years; p:0.003), irrespective of the anti-PM/Scl status.

\begin{tabular}{|c|c|c|c|}
\hline & anti.Pm/Scl + & anti-Pm/Scl. & p-value \\
\hline $\begin{array}{l}\text { Age at disease onset (years) } \\
\text { (mean (SD)) (n available) }\end{array}$ & $47.9(15.4)(123)$ & $49.5(14.3)(160)$ & 0.36 \\
\hline $\begin{array}{l}\text { Disease duration (months) } \\
\text { (mean (SD)) (n available) }\end{array}$ & $124.9(87.2)(123)$ & $111.3(77.1)(160)$ & 0.17 \\
\hline Male sex & $21 / 123(17.1)$ & 19/160 (11.9) & 0.23 \\
\hline Limited cutaneous subset & $92 / 123(74.8)$ & $119 / 160(74.4)$ & 1.00 \\
\hline Smoke (currentprevious) & $32 / 121(26.4)$ & $60 / 157(38.2)$ & 0.04 \\
\hline Caucasian ethnicity & $110 / 114(96.5)$ & 133/143 (93.0) & 0.27 \\
\hline Raynaud's phenomenon & $115 / 118(97.5)$ & $158 / 159(99.4)$ & 0.32 \\
\hline Esophageal symptoms & $69 / 123(56.1)$ & $121 / 160(75.6)$ & $<0.0001$ \\
\hline Scleroderma renal crisis & $5 / 123(4.1)$ & $3 / 153(2.0)$ & 0.25 \\
\hline Active digital ulcers & 13/123(10.6) & 22160 (13.8) & 0.47 \\
\hline Joint synovitis & $23 / 123(18.7)$ & $36 / 158(22.8)$ & 0.46 \\
\hline Arrythmia requiring specific therapy & $7 / 122(5.7)$ & $22159(13.8)$ & 0.03 \\
\hline Lung fibrosis on HRCT & $78 / 119(65.5)$ & $531152(34.9)$ & $<0.0001$ \\
\hline PAH confirmed on RHC & $4 / 123(3.3)$ & 12/158 (7.6) & 0.19 \\
\hline Clinical signs of myositis & $45 / 123(36.6)$ & $17 / 160(10.6)$ & $<0.0001$ \\
\hline Calcinosis & $42 / 123(34.1)$ & $34 / 157(21.7)$ & 0.02 \\
\hline Doath (any cause) & $8 / 123(6.5)$ & $7 / 160(4.4)$ & 0.44 \\
\hline GAVE & $3 / 123(24)$ & $0 / 160(0)$ & 0.08 \\
\hline Malignancies (ever) & $14 / 120^{*}(11.7)$ & $9 / 155^{*}(5.8)$ & 0.12 \\
\hline Malignancies synchronous ( \pm 2 years) & $4 / 120^{*}(3.3)$ & $3 / 155^{*}(1.9)$ & 0.70 \\
\hline
\end{tabular}

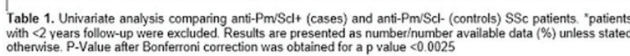

Conclusion: in this EUSTAR multicentre case control-study, the association of anti-Pm/Scl with malignancies in SSc patients could not be confirmed. Patients with older age at SSc onset seems to be at higher risk for synchronous malignancies, regardless the autoantibody status.

\section{REFERENCES:}

[1] Lazzaroni MG, et al. Ann Rheum Dis 2018; 77:(Suppl 2), 421-422.

[2] Bruni C, et al. Rheumatology (Oxford). 2017;56:317-8.

[3] Bernal-Bello D, et al. Autoimmun Rev 2017;16:461-8.
Acknowledgement: Authors would like to thank GILS (Gruppo Italiano Lotta Sclerodermia) for the grant to support this project

Disclosure of Interests: Maria Grazia Lazzaroni: None declared, Stefania Zingarelli: None declared, Jeska de Vries-Bouwstra: None declared, Eric Hachulla Consultant for: Received consulting fees or other remuneration from Actelion, GSK, Pfizer, and Bayer, Elisabetta Zanatta: None declared, Simone Barsotti: None declared, Marie-Elise Truchetet: None declared, Giacomo De Luca Speakers bureau: Pfeizer, Sobi, Vanessa Smith: None declared, Ellen De Langhe: None declared, Roger Hesselstrand: None declared, Francesca Ingegnoli: None declared, Cristian Caimmi: None declared, Silvia Bellando Randone: None declared, Enrico Colombo: None declared, Angela Ceribelli: None declared, Franco Franceschini: None declared, Yannick Allanore Grant/research support from: Inventiva, F Hoffman La-Roche, Sanofi, BMS, Pfizer, Consultant for: Actelion, Bayer, BMS, Boehringer, Roche, Sanofi, Paolo Airò: None declared

DOI: 10.1136/annrheumdis-2019-eular.5569

\section{FRI0331 HISTORY OF SILICA DUST EXPOSURES AND ASSOCIATION WITH CHEST HRCT AND CLINICAL CHARACTERISTICS IN SYSTEMIC SCLEROSIS}

Alice Ballerie ${ }^{1}$, Catherine Cavalin ${ }^{2}$, Mathieu Lederlin ${ }^{3}$, Amélie Nicolas ${ }^{4}$, Ronan Garlantezec ${ }^{5}$, Stéphane Jouneau ${ }^{5}$, Claire Cazalets ${ }^{6}$, Nicolas Belhomme ${ }^{7}$ Paul-Andre Rosental ${ }^{8}$, Patrick Jégo ${ }^{5}$, LESCOAT Alain ${ }^{5}$, SILICOSIS project, ERC Advanced Grant. ${ }^{1}$ Univ Rennes, CHU Rennes, Inserm, EHESP, Irset (Institut de recherche en santé, environnement et travail) - UMR S 1085, Rennes, France; ${ }^{2}$ Centre d'etudes europeennes de Sciences Po, 79363, Paris, France; ${ }^{3} \mathrm{CHU}$ Rennes, Univ Rennes, Radiology, Rennes, France; ${ }^{4} \mathrm{CHU}$ Rennes, Univ Rennes, Radiology, Rennes, France; ${ }^{5}$ Univ Rennes, CHU Rennes, Inserm, EHESP, Irset (Institut de recherche en santé, environnement et travail) - UMR_S 1085, Rennes, France; ${ }^{6} \mathrm{CHU}$ Rennes, Univ Rennes, Internal medicine and clinical immunology, Rennes, France; ${ }^{7} \mathrm{CHU}$ Rennes, Univ Rennes, Internal medicine and clinical immunology, Rennes, France; ${ }^{8}$ SILICOSIS project, ERC Advanced Grant, Centre for European Studies, Sciences Po and National Institute for Demographic Studies (INED), Paris, France

Background: The association of a history of silica exposure with precise chest high-resolution computed tomography (HRCT) features are still to be determined in SSc patients fulfilling the 2013 EULAR/ACR classification criteria. A recent study highlighted that mediastinal lymph nodes were associated with worse prognosis in all-cause interstitial lung diseases (ILD) (1). Nonetheless, the links between mediastinal lymphadenopathies (LA) and silica exposure in SSc patients have never been studied to date.

Objectives: The aim of this study was to assess the association of exposures to inorganic particles on the whole life course, with the HRCT characteristics in an unselected population of SSc patients.

Methods: A specific questionnaire based on a multidisciplinary approach (social sciences, epidemiology, occupational health and medicine) was used to assess occupational and non-occupational exposures to inorganic particles, with a specific interest on silica exposures in 100 SSc patients fulfilling the 2013 EULAR/ACR classification criteria. Clinical characteristics and chest HRCT at diagnosis were evaluated to assess the association of dust exposure with disease characteristics. The most recent chest HRCT was also evaluated and compared to HRCT at diagnosis to assess pulmonary evolution. All HRCT were evaluated by 3 experts, blinded for the results form dust exposure questionnaire.

Results: Men had significantly higher global and occupational dust-exposure scores than women. Sixty-five percent of men with SSc $(n=17)$ had an occupational exposure to silica. Thirty-five percent of patients had thoracic LA and $12 \%$ an association of mediastinal and hilar LA. Male gender, history of tobacco use, dcSSc, positivity for ATA, thoracic LA and pneumoconiosis were significantly associated with occupational exposure to silica $(\mathrm{p}<0.05$ for all). The presence of mediastinal and hilar LA was also associated with occupational exposure to silica $(p=0.0001$ $\mathrm{OR}=13.45,95 \% \mathrm{Cl}=3.46-52.27)$. After stratification on gender, higher occupational dust-exposure score in men remained associated with mediastinal and hilar LA ( $\mathrm{p}=0.046, \mathrm{OR}=6.5,95 \% \mathrm{Cl}=1.09-38.63$ ). Mediastinal and hilar LA were also significantly associated with a more severe evolution of pulmonary involvement in SSc when considering extensive ILD at diagnosis, the use of immunosuppressive drugs, a fibrotic evolution with change of SSc-ILD pattern in the course of the disease, and an increase of pathological parenchyma extent above $10 \%$ since diagnosis.

Conclusion: By using a dedicated highly detailed questionnaire, this study underscores the high prevalence of silica exposure in SSc patients, especially in men. Mediastinal and hilar LA, considered as a bad prognostic factor in ILD, were frequent and associated with silica exposure. 


\section{REFERENCES:}

[1] Adegunsoye A, et al. Prognosticating Outcomes in Interstitial Lung Disease by Mediastinal Lymph Node Assessment: An Observational Cohort Study with Independent Validation. Am J Respir Crit Care Med. 2018 Sep 14

Disclosure of Interests: None declared DOI: 10.1136/annrheumdis-2019-eular.7632

\section{FRI0332 IL-2 RESTORED THE REDUCED ABSOLUTE NUMBER OF TREG CELLS IN THE PATIENTS WITH IDIOPATHIC INFLAMMATORY MYOPATHY}

Yuying Liang ${ }^{1}$, Hong-Yan Wen ${ }^{2}$, Yanan Duann ${ }^{2}$, Yang Liư ${ }^{3}$, Zhen $\mathrm{Yu}^{2}$, Chong Gao ${ }^{4}$. ${ }^{1}$ the Second Hospital of Shanxi Medical University, Rheumatology, Taiyuan, China; ${ }^{2}$ the Second Hospital of Shanxi Medical University, Rheumatology, Taiyuan, China; ${ }^{3}$ Shanxi Dayi Hospital Affiliated to Shanxi Medical University, Rheumatology, Taiyuan, China; ${ }^{4}$ Brigham and Women's Hospital, Harvard Medical School, Department of Pathology, Boston, United States of America

Background: Idiopathic inflammatory myositis (IIM) is a group of skeletal muscle non-suppurative inflammatory disease, including polymyositis (PM), dermatomyositis (DM), inclusion body myositis (IBM), DM/PM associated with malignancy and so on. The latest studies suggest that there is an increase of Th17 cells levels and a decrease of regulatory $T$ cells (Tregs) levels in IIM, which lead to the Th17/Treg imbalance. IL-2 promotes the proliferation and differentiation of several subsets of $C D 4^{+} T$ cells and inhibits Th17 cells. It is provided to Tregs from IL-2-producing cells such as activated $\mathrm{CD} 4^{+} \mathrm{CD} 25^{\text {low }} \mathrm{T}$ cells, NK and NKT cells. Tregs express IL-2R $\alpha \beta \gamma$, a high affinity IL-2 receptor complex. Therefore, Tregs may be selectively stimulated by low-dose IL-2 and amplified.

Objectives: To explore the quantitative changes of peripheral Th17 cells and Tregs in IIM before and after receiving treatment with low-dose interleukin-2 (IL-2) and analyze the relationship between peripheral Th17 cells and Tregs and clinical indicators disease activity.

Methods: Total 151 IIM patients were enrolled, and 196 healthy adults were used as normal controls. Of them, 76 cases were treated with low dose IL-2 $\left(5.0^{*} 10^{5}\right.$ international units (IU) for 5 days). The absolute number of peripheral $\mathrm{T}, \mathrm{CD} 4^{+} \mathrm{T}, \mathrm{CD} 8^{+} \mathrm{T}, \mathrm{Th} 1, \mathrm{Th} 2, \mathrm{Th} 17$ and Treg subsets were analyzed by flow cytometry. Laboratory examinations were analyzed retrospectively. Since the data was disregarded from the normal distribution, the median four quantile method was used for statistical description. Multiple samples were compared with Kruskal-Wallis $\mathrm{H}$ test, and the correlation between variables was Spearman rank correlation analysis.

Results: (1) In the patients, the absolute number of Treg cells was significantly decreased as compared with that in the control group $(P<0.05)$ and increased by treated with a low dose IL-2. After IL-2 treatment, the absolute numbers of $\mathrm{T}, \mathrm{CD}^{+} \mathrm{T}, \mathrm{CD}^{+} \mathrm{T}, \mathrm{Th} 1, \mathrm{Th} 2$ and Th17 cells and the ratio of Th17/Treg were still significantly lower than that in the control group $(P<0.05)$; the ratio of Th17/Treg in the patients was not significantly different from that in the control group $(P>0.05)$. (2) The peripheral Th17 cells levels were negatively correlated with ESR, CRP, LDH and HBDH $(r=-0.42, \quad r=-0.28, \quad r=-0.21, \quad r=-0.20, \quad P<0.05)$; the peripheral Treg cells levels were negatively correlated with ESR, CRP, LDH and HBDH $(r=-0.18, r=-0.20, r=-0.18, r=-0.20, \quad P<0.05)$; the ratio of Th17/Treg was negatively correlated with ESR $(r=-0.23, P<0.05)$.

Conclusion: The absolute number of peripheral Th17 cells and Tregs declined significantly in IIM, and had correlation with ESR, CRP, LDH and $\mathrm{HBDH}$. However, after receiving treatment with low-dose IL-2, the Tregs levels elevated, which means that IL-2 may plays an essential role in the differentiation and development of Tregs. It also provides new thought and strategy for the therapy of IIM.

\section{REFERENCES:}

[1] Noack M, Miossec P. Th17 and regulatory T cell balance in autoimmune and inflammatory diseases [J]. Autoimmunity reviews, 2014, 13(6): 668677.

[2] Bluestone J A, Trotta E, Xu D. The therapeutic potential of regulatory T cells for the treatment of autoimmune disease[J]. Expert opinion on therapeutic targets, 2015, 19(8): 1091-1103.

[3] Peterson, L. B., Bell, C. J. M., Howlett, S. K. A long-lived IL-2 mutein that selectively activates and expands regulatory $T$ cells as a therapy for autoimmune disease[J]. Journal of Autoimmunity, 2018, 95: 1-14.

[4] Fan, M. Y., Low, J. S., Tanimine, N. Differential Roles of IL-2 Signaling in Developing versus Mature Tregs[J]. Cell Reports, 2018, 25(5): 1204-1213.

Disclosure of Interests: None declared
DOI: 10.1136/annrheumdis-2019-eular.6656

\section{FRI0333 ASSESSING SYSTEMIC SCLEROSIS CARDIAC INVOLVEMENT USING MAGNETIC RESONANCE T1- MOLLI MAPPING}

Sue-Ann $\mathrm{Ng}^{1,2}$, Stephanie Marchesseau ${ }^{3}$, John Carson Allen $\mathrm{Jr}^{2}$, John Totman ${ }^{3}$, Andrea Low ${ }^{1,2}$. 'Singapore General Hospital, Rheumatology and Immunology, Singapore, Singapore; ${ }^{2}$ Duke-National University of Singapore, Singapore, Singapore; ${ }^{3}$ Clinical Imaging Research Center, $A^{*}$ STAR and National University of Singapore, Singapore, Singapore

Background: Patients with systemic sclerosis (SSc) and symptomatic cardiac involvement have a disease-associated mortality of $20 \%$ in 10 years. Prevalence of subclinical cardiac involvement is 15\%-35\%. Early diagnosis and monitoring is therefore critical in the management of SSc-associated cardiac involvement. Conventional cardiac magnetic resonance imaging (cMRI) T1-weighted sequence with late gadolinium contrast has good accuracy for detecting localized fibrosis but not diffuse fibrosis that occurs in SSc. Modified look-locker inversion recovery (T1-MOLLI) mapping, a novel cMRI sequence, has been used to detect and quantify diffuse fibrosis in aortic stenosis. T1-MOLLI values have also been correlated with the degree of biopsy-quantified fibrosis.

Objectives: To investigate whether cMRI T1-MOLLI is able to detect fibrosis associated with SSc cardiac involvement.

Methods: We recruited 16 patients fulfilling the 2013 ACR/EULAR criteria for SSc and 17 healthy age-matched (within 5 years) controls. Patients underwent cMRI T1-MOLLI mapping on the Siemens Biograph mMR 3.0T (Erlanger, Germany).

T1-MOLLI values were compared between SSc patients and healthy con trols using student t-test and statistical significance was taken to be $\mathrm{p}<0.05$.

Results: Demographics and clinical features of our study cohort are as shown in Table 1. Two (12.5\%) SSc patients were symptomatic with palpitations or had arrhythmia requiring treatment. Eleven (68.8\%) SSc patients had elevated T1 MOLLI values, using a normal cut-off threshold of $1284 \mathrm{~ms}$

Mean cardiac T1 values were significantly higher in SSc patients (1329 \pm $88.0 \mathrm{~ms}$ ) than in controls (mean $\mathrm{T} 1=1238 \pm 93.7 \mathrm{~ms}, \mathrm{p}=0.0075$ ), indicating the presence of cardiac fibrosis.

Conclusion: cMRI T1-MOLLI mapping demonstrated that SSc patients who were predominantly asymptomatic showed evidence of cardiac fibrosis cMRI T1-MOLLI is potentially a useful diagnostic and monitoring tool for SSc cardiac disease.

Table 1. Demographics and clinical features

\begin{tabular}{|c|c|c|}
\hline & $\begin{array}{l}\text { SSc patients } \\
\qquad(\mathrm{n}=16)\end{array}$ & $\begin{array}{c}\text { Controls } \\
(n=17)\end{array}$ \\
\hline Limited/Diffuse SSc, $n$ & $11 / 5$ & $\begin{array}{c}\text { Not } \\
\text { applicable }\end{array}$ \\
\hline Female, n (\%) & $14(87.5 \%)$ & $14(82.3 \%)$ \\
\hline Age, years & $49.2 \pm 13.9$ & $51.5 \pm 14.8$ \\
\hline $\begin{array}{l}\text { Mean disease duration from Raynaud's phenomenon } \\
\text { onset, years }\end{array}$ & $6.1 \pm 7.3$ & $\begin{array}{l}\text { Not } \\
\text { applicable }\end{array}$ \\
\hline $\begin{array}{l}\text { Mean disease duration from non-Raynaud's phenomenon } \\
\text { onset, years }\end{array}$ & $6.6 \pm 7.4$ & $\begin{array}{c}\text { Not } \\
\text { applicable }\end{array}$ \\
\hline Hypertension, n (\%) & $4(25 \%)$ & $1(5.9 \%)$ \\
\hline Palpitations, n (\%) & $2(12.5 \%)$ & 0 \\
\hline Arrhythmia requiring treatment, $\mathrm{n}(\%)$ & $2(12.5 \%)$ & 0 \\
\hline Anti-centromere positivity, (n) & 3 & $\begin{array}{l}\text { Not } \\
\text { applicable }\end{array}$ \\
\hline Anti-Topo-I positivity, (n) & 4 & $\begin{array}{l}\text { Not } \\
\text { applicable }\end{array}$ \\
\hline
\end{tabular}

Disclosure of Interests: None declared

DOI: 10.1136/annrheumdis-2019-eular.6892

\section{FRI0334 PERFORMANCE OF THE SCLERODERMA SKIN PATIENT-REPORTED OUTCOME (SSPRO) IN A PHASE 2 TRIAL WITH LENABASUM}

Ada Man ${ }^{1}$, Nancy Dgetluck ${ }^{2}$, Brian Conley ${ }^{2}$, Barbara White ${ }^{2} .{ }^{1}$ University of Manitoba, Winnipeg, Canada; ${ }^{2}$ Corbus Pharmaceuticals, Inc., Norwood, United States of America

Background: Skin thickening is a distressing feature of systemic sclerosis (SSc). The severity and extensiveness of skin thickening, as traditionally 